Article

\title{
Warming and Eutrophication Effects on Phytoplankton Community of Two Tropical Systems with Different Trophic States-An Experimental Approach
}

\author{
Andreia Maria da Anunciação Gomes 1,2,*,t, Marcelo Manzi Marinho 3,t, \\ Marcella Coelho Berjante Mesquita ${ }^{3}$, Ana Carolina Coelho Prestes ${ }^{3}$, Miquel Lürling ${ }^{4,5}$ \\ and Sandra Maria Feliciano De Oliveira E Azevedo ${ }^{1}$ \\ ${ }^{1}$ Laboratório de Ecofisiologia e Toxicologia de Cianobactérias, $\mathrm{IBCCF}^{\circ}$, Universidade Federal do Rio de \\ Janeiro, CCS Bl.G, 21941-902 Rio de Janeiro, Brasil \\ ${ }^{2}$ Laboratório de Botânica, Instituto de Recursos Naturais, Universidade Federal de Itajubá, Av. BPS, 1303, \\ Pinheirinho, 37500-903 Itajubá, MG, Brasil \\ ${ }^{3}$ Laboratório de Ecologia e Fisiologia do Fitoplâncton, Departamento de Biologia Vegetal, Universidade do \\ Estado do Rio de Janeiro, 20550-900 Rio de Janeiro, Brasil \\ ${ }^{4}$ Aquatic Ecology \& Water Quality Management Group, Department of Environmental Sciences, Wageningen \\ University, 6708 PB Wageningen, The Netherlands \\ ${ }^{5}$ Department of Aquatic Ecology, Netherlands Institute of Ecology (NIOO-KNAW), 6708 PB Wageningen, \\ The Netherlands \\ * Corresponding author: Andreia M A Gomes, Tel. +55 35 36291804, Fax, +55 3536223596 , e-mail: \\ amagomes@unifei.edu.br
}

† Both authors contributed equally to this work

\begin{abstract}
Global warming, as well as europhication are predicted to promote cyanobacterial blooms, but how tropical phytoplankton communities from different trophic state systems respond to temperature variation is less known. To further explore the effect of temperature changes and nutrient addition on phytoplankton communities and to get insight in possible resistance to these effects, we tested the hypothesis that temperature variation will have a stronger effect on cyanobacteria dominance in eutrophic water than in oligo-mesotrophic. Hereto, we conducted an experiment with phytoplankton communities from two aquatic ecosystems differing in trophic state. Water samples from a eutrophic and an oligo-mesotrophic system were collected and incubated in 25 and $30^{\circ} \mathrm{C}$. Also, treatments that received additional surplus $\mathrm{N}$ and $\mathrm{P}$ were included that served as eutrophication treatments. Temperature variation itself did not promote cyanobacteria in either water from the oligo-mesotrophic or the eutrophic system. However, nutrient enrichment of water from the eutrophic system significantly boosted cyanobacteria, and biomass increased 10 times in both $25^{\circ} \mathrm{C}$ and $30^{\circ} \mathrm{C}$ treatments. In contrast, eutrophication of water from the oligo-mesotrophic system did not change the relative contribution of phytoplankton groups and response ratios were much lower than those for water from the eutrophic system. Although using a very simple experimental design, the results suggest that in eutrophic systems cyanobacteria dominance can be favoured by further addition of nutrients, independently of a direct temperature effect and that more pristine environments possess some resistance against eutrophication. Since global warming is assumed to intensify eutrophication symptoms indirectly, our study underscores the importance of nutrient control.
\end{abstract}

Key words: global warming; nutrients addition; cyanobacterial blooms; eutrophic systems; oligo-mesotrophic systems 


\section{Introduction}

Human activities are causing severe alterations in ecosystems worldwide. In particular, freshwater ecosystems are being transformed rapidly [1]. These systems have experienced altered precipitation patterns, more intense and longer periods of thermal stratification, modified hydrology, elevated carbon dioxide concentration, increased nutrient loading and elevated temperatures as a consequence of global change [2,3]. Furthermore, these changes will probably be intensified in the next decades following both the expected increase in global temperatures and inputs of anthropogenic nutrients [4]. Phytoplankton, as primary producers of aquatic ecosystems, can be considered a target to experience these environmental changes since nutrient availability and temperature are among the main conditions that drive competitive advantage and regulate phytoplankton species distribution [5]. Some studies indicate that increasing nutrients and temperatures may exert a synergistic effect on cyanobacteria dominance [6,7]. Actually, of all of potential environmental drivers behind cyanobacterial blooms, the one that has received the most attention among the scientific community has been anthropogenic eutrophication. Nutrient availability, mainly nitrogen and phosphorus, has been indicated as a primary factor in the expansion of blooms [8]. But, the direct and indirect effects of temperature have also been associated with phytoplankton composition changes, especially pointing that cyanobacteria are more favoured by elevated temperature than eukaryote competitors $[2,6,9]$.

Different works have reported that in the current century, the global temperature is expected to increase an additional 1.5 to $5^{\circ} \mathrm{C}$ above today's mean by 2100 (Hansen et al., 2000) and anthropogenic nutrients inputs will have doubled by 2050 [11]. Recent observations have shown that the effects of climate warming and eutrophication in U.S. lakes are dependent on trophic state [12]. Nutrients played a role in oligotrophic lakes, while temperature was important to mesotrophic lakes and the interactions between these two factors were only important in eutrophic and hyper-eutrophic systems [12]. To date, most information about possible effects of global change on freshwater ecosystems has been based on temperate lake systems [13], which to emphasises the urgent need for more data on understudied tropical lake systems.

In this context, the objective of this study was to examine the effect of temperature alone and in combination with high nutrient addition on phytoplankton communities from tropical ecosystems of two different trophic states. In particular we tested the hypotheses that 1) temperature variation favours cyanobacteria growth more than that of eukaryote competitors, 2) temperature variation will have a stronger effect on cyanobacteria dominance in tropical eutrophic water than in oligo-mesotrophic water and 3) nutrient addiction will promote a stronger effect on cyanobacteria favoring in oligo-mesotrophic water than eutrophic water.

\section{Results}

\subsection{Effect of temperature variation and eutrophication on tropical phytoplankton communities}

The $5^{\circ} \mathrm{C}$ temperature variation was not an important factor to change the phytoplankton composition, in both experimental conditions with water from the eutrophic and oligo-mesotrophic system (Fig. 1a,c and 2a,c). At start of the experiment, the phytoplankton community of the eutrophic system was dominated by cyanobacteria (mean of all treatments: $88 \%$ of total biomass) with an average biomass of $127 \mu \mathrm{g}$ chlorophyll- $a \mathrm{~L}^{-1}$. At the end of the experiment, cyanobacteria (mean: $70 \%$ ) remained dominant over eukaryote algae (mean: $30 \%$ ) in both treatments, $25^{\circ} \mathrm{C}$ and $30^{\circ} \mathrm{C}$ (Table I). The biomass of these treatments never exceeded $250 \mu \mathrm{g} \mathrm{L}^{-1}$ for cyanobacteria and 60 $\mu \mathrm{g} \mathrm{\textrm {L } ^ { - 1 }}$ for eukaryote algae over the entire experimental period (Fig 1a and 1c). Also when nutrients were added cyanobacteria remained dominant (mean: 97.3\%). However, nutrient additions boosted cyanobacteria biomass that increased from $124.1( \pm 1.9) \mu \mathrm{g} \mathrm{L}^{-1}$ to $1331.7( \pm 48.9) \mu \mathrm{g} \mathrm{L} \mathrm{L}^{-1}$ in $25^{\circ} \mathrm{C} \mathrm{N}+\mathrm{P}$ and from $125.3( \pm 4.53) \mu \mathrm{g} \mathrm{L^{-1 }}$ to $1264.0( \pm 124.0) \mu \mathrm{g} \mathrm{\textrm {L } ^ { - 1 }}$ in $30^{\circ} \mathrm{C} \mathrm{N}+\mathrm{P}$ treatments (Fig. $1 \mathrm{~b}$ and $1 \mathrm{~d}$, Table I). 


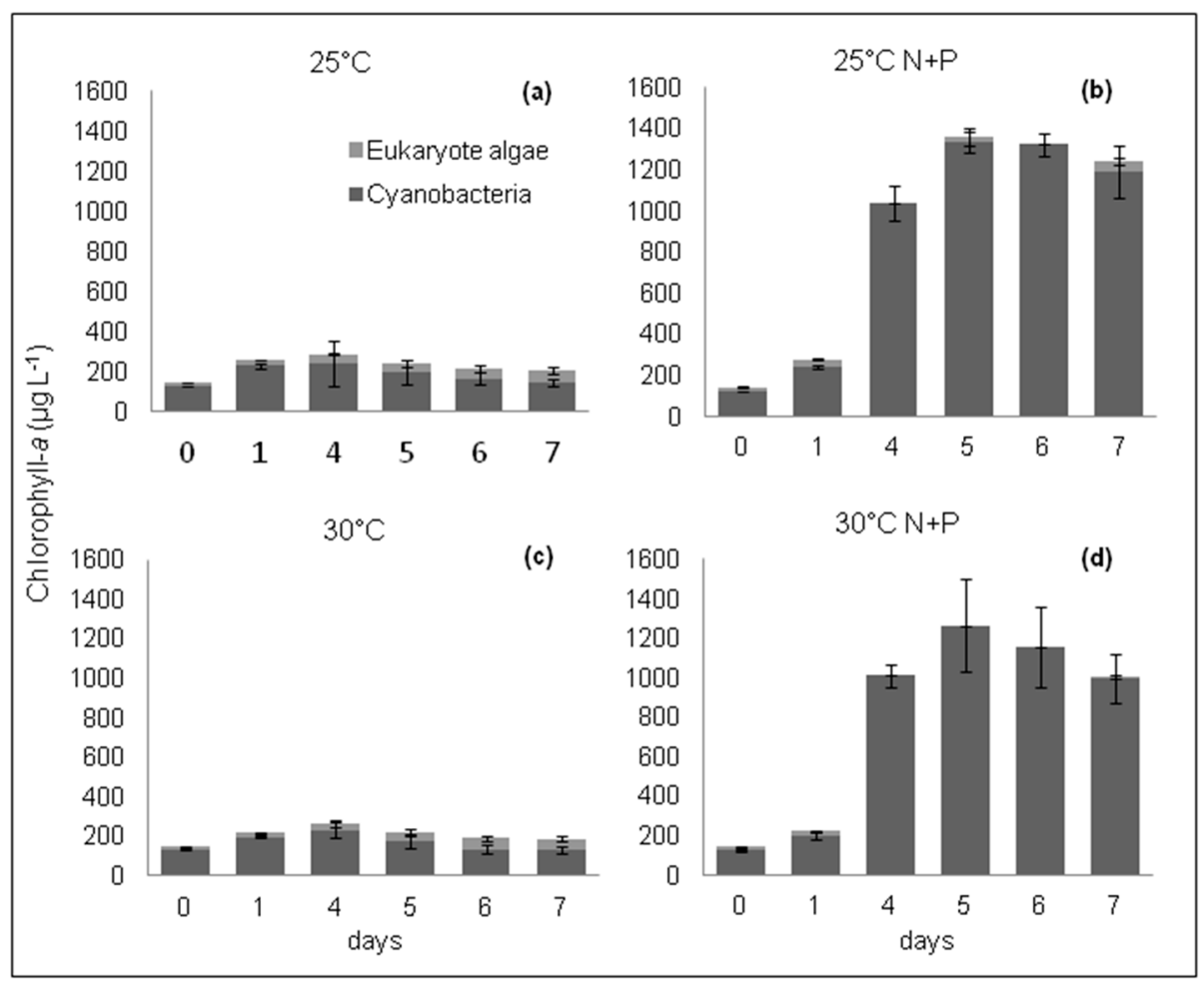

Figure 1: Eukaryote algae and Cyanobacteria biomass (based on chlorophyll- $a$ concentration) in the experiments with Eutrophic system phytoplankton community. Error bars indicate plus or minus one standard error.

In water from the oligo-mesotrophic system at start of the experiment, eukaryote algae were more abundant (mean contribution for all treatments: 66.4\%) than cyanobacteria (mean for all treatments: $33.6 \%$ ). During the first three days of the experimental period the share of cyanobacteria in the phytoplankton community increased in all treatments, reaching about $50 \%$, where after it was maintained until the end of experiment (Fig. 2a and 2c). The temperature variation, from $30^{\circ} \mathrm{C}$ to $25^{\circ} \mathrm{C}$, did not change the contribution of phytoplankton groups and total biomass without nutrient additions remained $<20 \mu \mathrm{g}$ chlorophyll- $a \mathrm{~L}^{-1}$ (Fig. 2a and 2c). Addition of nutrients caused a slight increase to about $30 \mu \mathrm{g} \mathrm{L}^{-1}$ in the $30^{\circ} \mathrm{C} \mathrm{N}+\mathrm{P}$ treatments (Fig. $2 \mathrm{~d}$ ) and a stronger increase from 11 to $60 \mu \mathrm{g} \mathrm{L} \mathrm{L}^{-1}$ in the $25^{\circ} \mathrm{C} \mathrm{N}+\mathrm{P}$ treatments (Fig. $2 \mathrm{~b}$, Table I).

Table I: Chlorophyll- $a$ concentration ( $\mu \mathrm{g} \mathbf{L}^{-1} \pm$ standard error) and relative contribution based on chlorophyll- $a(\%)$ of Cyanobacteria and Eukaryote algae at the beginning and the end of experimental period.

\section{OLIGO-MESOTROPHIC SYSTEM}

\section{Eukaryote algae}

\section{Treatment days}

$25^{\circ} \mathrm{C}$

0

$10.0( \pm 2.8)$
Chl-a

7
$8.9( \pm 0.7)$

7

\section{Cyanobacteria}

Chl-a

$\%$

71.7

$4.0( \pm 0.5)$

28.3

50.2

$8.8( \pm 1.3)$

49.8 
4 of 11

$\begin{array}{cccccc}\mathbf{2 5}^{\circ} \mathbf{C ~ N + P} & 0 & 7.3( \pm 0.2) & 66.7 & 3.7( \pm 0.4) & 33.3 \\ & 7 & 34.6( \pm 2.1) & 57.1 & 26.0( \pm 1.1) & 42.9 \\ \mathbf{3 0} 0^{\circ} \mathbf{C} & 0 & 7.0( \pm 0.1) & 63.0 & 4.1( \pm 0.1) & 37.0 \\ & 7 & 8.1( \pm 0.3) & 51.0 & 7.8( \pm 1.2) & 49.0 \\ \mathbf{3 0}^{\circ} \mathbf{C ~ N}+\mathbf{P} & 0 & 7.2( \pm 0.0) & 64.2 & 4.0( \pm 0.1) & 35.8 \\ & 7 & 11.0( \pm 2.3) & 41.0 & 15.8( \pm 5.4) & 59.0\end{array}$

\section{EUTROPHIC SYSTEM}

\section{Eukaryote algae}

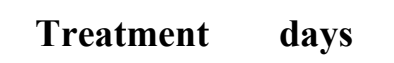

$25^{\circ} \mathrm{C}$

0

7

$25^{\circ} \mathrm{C} \mathrm{N}+\mathrm{P}$

0

7

$30^{\circ} \mathrm{C}$

0

7

$3^{\circ} \mathrm{C} \mathbf{N}+\mathbf{P}$

\section{Chl-a}

$17.9( \pm 0.9)$

$60.1( \pm 11.6)$

$16.8( \pm 2.3)$

$51.7( \pm 11.1)$

$16.4( \pm 1.0)$

$56.8( \pm 7.3)$

$16.2( \pm 2.2)$

$13.4( \pm 6.8)$
$\%$

12.4

29.4

11.9

4.2

11.2

30.2

11.4

1.3

\section{Cyanobacteria}

\section{Chl-a}

$\%$

87.6

70.6

88.1

95.8

88.8

69.8

88.6

98.7 


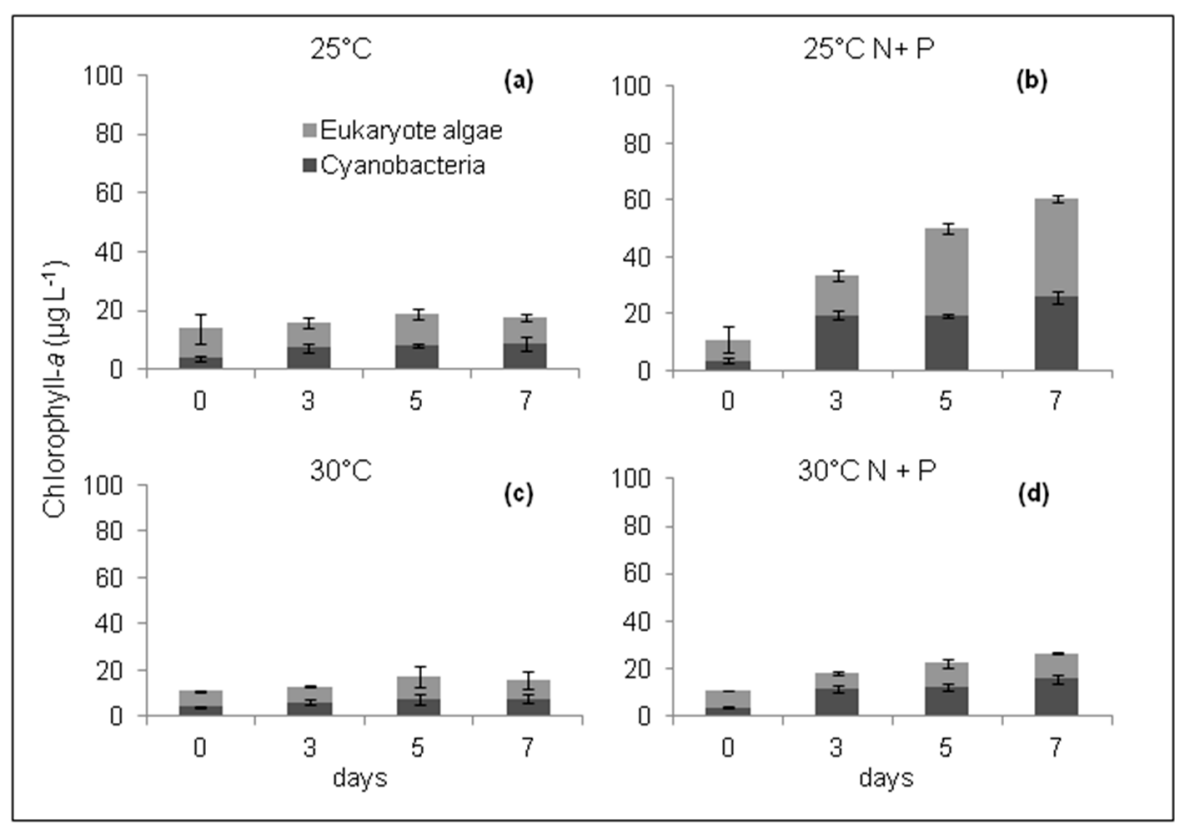

Figure 2: Eukaryote algae and Cyanobacteria biomass (based on chlorophyll- $a$ concentration) in the experiments with Oligo-mesotrophic system phytoplankton community. Error bars indicate plus or minus one standard error.

Warming in itself led to negative response ratios for both cyanobacteria ( $\left.R R_{\text {cyano }}\right)$ and eukaryote algae (RRalgae) in eutrophic system (Fig. 3), reflecting a decrease in biomass compared to the sole $25^{\circ} \mathrm{C}$ incubations. No significant difference was observed between $R R$ cyano and RRalgae eutrophic system at $30^{\circ} \mathrm{C}$ treatment $(p=0.807)$. The temperature decrease from $30^{\circ} \mathrm{C}$ to $25^{\circ} \mathrm{C}$, in oligo-mesotrophic system, promoted the positive response ratios for both cyanobacteria ( $\left.R R_{\text {cyano }}\right)$ and eukaryote algae (RRalgae), indicating the biomass increase with decrease of $5{ }^{\circ} \mathrm{C}$ of temperature.

However, nutrient additions either alone $\left(25^{\circ} \mathrm{C} N+\mathrm{P}\right)$ or in combination with higher temperature $\left(30^{\circ} \mathrm{C} \mathrm{N}+\mathrm{P}\right)$ resulted in different responses in water from the eutrophic and the oligo-mesotrophic system (Fig. 3). In water from the eutrophic system, nutrient addition caused a strong positive response ratio of cyanobacteria, while eukaryote algae remained a negative response ratio. The elevated temperature and nutrient addition $\left(30^{\circ} \mathrm{C} \mathrm{N}+\mathrm{P}\right)$ intensified the negative response ratio of eukaryote algae. The $R R_{\text {cyano }}$ was significantly higher than $R R_{\text {algae }}(\mathrm{p}=0.002)$. In contrast, $R R_{\text {algae }}$ in water from the oligo-mesotrophic system were positive in both in nutrient enriched treatments $\left(25^{\circ} \mathrm{C} \mathrm{N}+\mathrm{P}\right.$ and $30^{\circ} \mathrm{C} \mathrm{N}+\mathrm{P}$ ) (Fig. 3), but significantly higher than $\mathrm{RR}_{\text {cyano }}$ only in $25^{\circ} \mathrm{C} \mathrm{N}+\mathrm{P}$ treatment $(p<0.001)$. Nutrient addition led to a weaker positive $R R_{\text {cyano }}$ in the oligo-mesotrophic water when compared with the eutrophic water (Fig.3). 


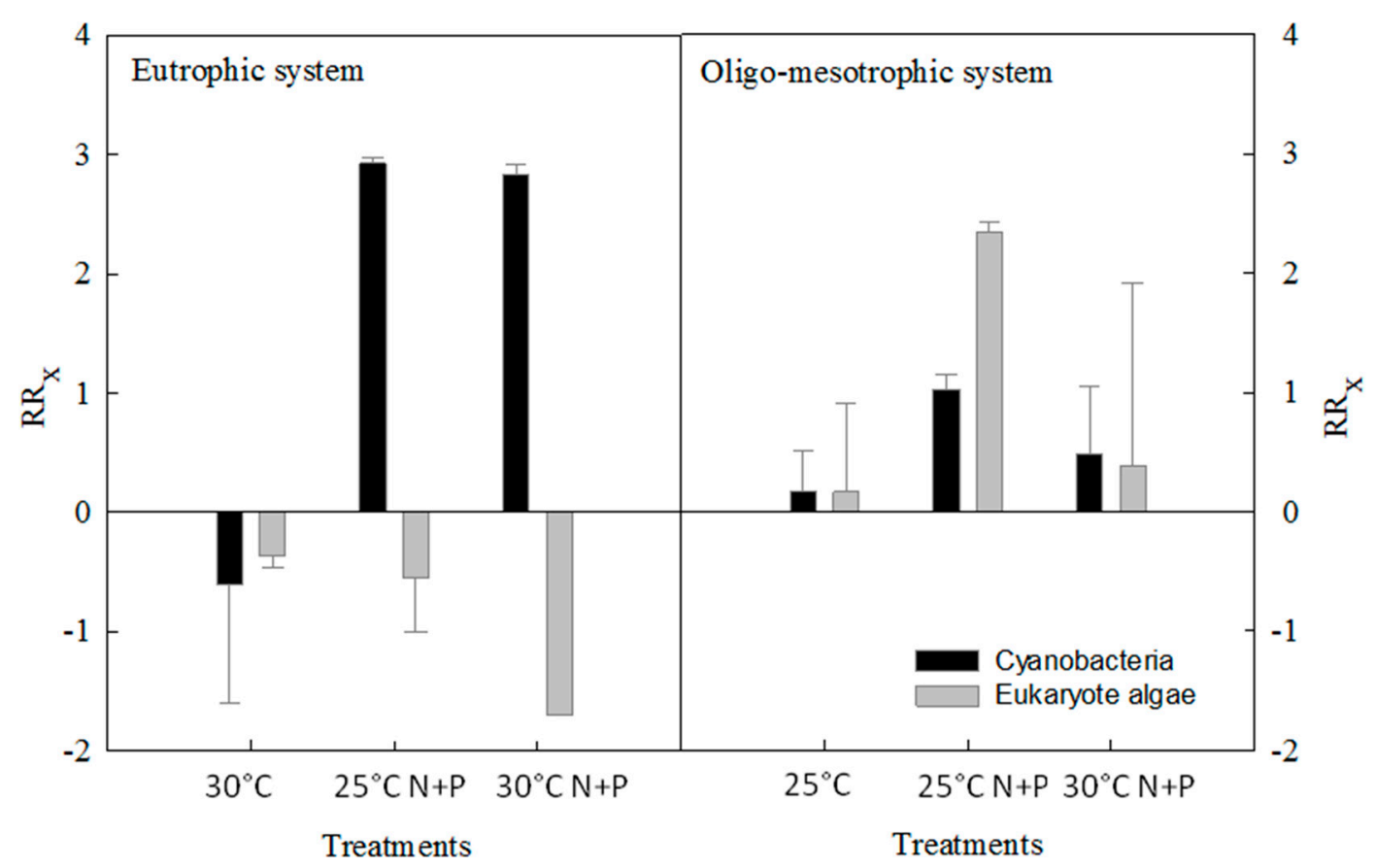

Figure 3: Response ratio of cyanobacteria and eukaryotic algae growth rate to each treatment $\left(25^{\circ} \mathrm{C}\right.$, $30^{\circ} \mathrm{C}, 25^{\circ} \mathrm{C} \mathrm{N}+\mathrm{P}$ and $30^{\circ} \mathrm{C} \mathrm{N}+\mathrm{P}$ ) in Eutrophic system and Oligo-mesotrophic system experiments. Error bars indicate plus or minus one standard error.

\section{Discussion}

3.1. What is the effect of temperature and eutrophication on phytoplankton communities from tropical ecosystems of different trophic states?

Our results clearly showed that temperature in itself did not lead to higher cyanobacteria biomass in the experiment with water from an oligo-mesotrophic and a eutrophic system. In fact, response ratios even were negative meaning phytoplankton biomass declined in eutrophic system. In oligo-mesotrophic system, the small increase in phytoplankton biomass at $25^{\circ} \mathrm{C}$ seems to indicate that higher temperatures can promote damage in phytoplankton community. Hence, the importance of a direct warming effect on freshwater phytoplankton - and particularly on stimulation of cyanobacteria - may be questioned. It seems more likely that indirect effects of warming such as increased thermal stratification and water column stability will promote cyanobacteria (with buoyancy control) over non-flagellate eukaryote algae [3]. However, by far the most important driver of cyanobacteria blooms is increased nutrient concentrations [14].

Our results showed that adding extra nutrients caused higher phytoplankton biomass in water from both the oligo-mesotrophic and the eutrophic system. The response was much stronger in water from the eutrophic system in which cyanobacteria biomass was boosted to very high levels. However, there was no synergism between nutrient addition and temperature in the cyanobacteria development, as was suggested recently to play a role in eutrophic and hyper-eutrophic systems [12]. Thus, also under high nutrient conditions we found no evidence of a temperature effect on cyanobacteria biomass. Nonetheless, the results provide further evidence that eutrophic lakes with cyanobacterial blooms can also be sensitive to nutrient pulses giving further raise of cyanobacteria biomass; creating an even worse scenario. In high-nutrient systems, light might become a limiting factor steering cyanobacteria development [12]. Yet, some cyanobacteria species (f.e. Planktothrix agardhii) are particularly equipped to thrive under such conditions [15].

The difference in response to nutrient addition between water from the oligo-mesotrophic and the eutrophic system underpins that lowering the nutrient status of lakes will render them less 
vulnerable to predicted effects of global changes [14]. These are likely the indirect effects that favor cyanobacteria biomass accumulation either at the water surface as a consequence of water column stability, or when populations are fueled from enhanced internal nutrient release and pulsed nutrient additions following precipitation. Such indirect effects may be more important than direct effects on growth $[3,16]$. Hence, the lower biomass observed in oligo-mesotrophic systems seems to enhance resistance against nutrient pulses as is evident from the lower RRcyano found in this study.

The share of cyanobacteria in the phytoplankton community was lower in water from the oligo-mesotrophic system than in water from the eutrophic system, which was expected from the general tendency of cyanobacteria dominance in eutrophic systems [17]. In a shallow lake survey spanning several climate regions, temperature was determined as the single most explanatory variable of the percent cyanobacteria in the phytoplankton community [18]. However, in our experiment we did not observe an increase in the share of cyanobacteria when water from either the oligo-mesotrophic or the eutrophic system was incubated at higher temperature. Although the eutrophic water was already dominated by cyanobacteria $(88 \%)$, nutrients further stimulated cyanobacteria contribution to $97 \%$ of the total phytoplankton, but not warming. Likewise, only temperature variation had no significant effect on the share of cyanobacteria in water from the oligo-mesotrophic system. Microcystis spp. were the only cyanobacteria in both oligo-mesotrophic and eutrophic systems in the end of the incubation. This was not surprisingly since M. aeruginosa and M. panniformes were reported as dominant species in cyanobacterial blooms in Jacarepaguá lagoon and Samuel reservoir respectively [30,34].

The existence of oligotrophic and mesotrophic reservoirs in Brazil devoid of nuisance blooms e.g., Lopes et al. 2005 [19]; Soares et al. 2008 [20], in close vicinity to eutrophic reservoirs that suffer from cyanobacterial blooms [20-24] highlights that warmer temperature in itself is not a key driver of cyanobacterial blooms. Several studies have addressed that indirect effects of climate change through nutrient loading may be more important than direct effects of temperature increase [3,13], which points to eutrophication. Indeed, higher nutrient availability will allow more biomass build up, where pulsed fluxes after short, intense storms increasing soil erosion will further fuel cyanobacterial blooms [25]. In addition, warmer temperature could lead to more water column stability promoting cyanobacterial nuisance as is evidenced in studies showing that in typical heat wave years cyanobacterial nuisance depended on water column stability $[6,26]$. Water column stability was not included in our experiment as flasks were shaken twice a day. This, however, did not hamper cyanobacteria growth at all as strong cyanobacteria increase in the nutrient enriched eutrophic water treatments was observed. Nonetheless, water column stability is an important factor; even in oligo-mesotrophic lakes with low water column cyanobacteria biomass, wind-driven cyanobacteria scum accumulation may occur at certain near-shore sites, while open water might be quite clear [27]. Both aspects of warming -water column stability driven surface accumulation and enhanced nutrient loading - should urge water authorities for strong eutrophication control as only very low cyanobacteria biomass will be a guarantee for non-hazardous conditions. In tropical areas this might be even more necessary as tropical waters tend to be more vulnerable to eutrophication than temperate systems, because at elevated temperatures in shallow lakes loss of submerged vegetation and switch to cyanobacteria might occur at lower nutrient concentrations [28]. Thus, reduction in nutrient inputs are not only relevant to counteract indirect climate warming consequences in temperate shallow lakes [29], but also in tropic lakes.

\section{Methods}

\subsection{Evaluation of the effect of temperature variation and eutrophication on tropical Phytoplankton communities}

To evaluate the effect of temperature variation and nutrients addiction on phytoplankton communities from tropical ecosystems of different trophic states, water samples from an eutrophic system (Jacarepaguá lagoon) and from an oligo-mesotrophic system (Samuel reservoir) were collected. Jacarepaguá lagoon ( $22^{\circ} 55^{\prime} \mathrm{S}$ and $\left.43^{\circ} 17^{\prime} \mathrm{W}\right)$ is a water body located near the metropolitan 
area of Rio de Janeiro, southeast region of Brazil. It is a shallow (maximum depth: $1.5 \mathrm{~m}$ ), oligohaline lagoon, with a surface area of $3.7 \mathrm{~km}^{2}$ and annual mean water temperature of $25^{\circ} \mathrm{C}$ [30]. This system has undergone a eutrophication process over the last 30 years [31]. Unpublished data obtained during 2007/2008 and 2014 showed that DIN varied from 1.2 to $2.8 \mathrm{mg} \mathrm{L}^{-1}$ and SRP from 0.4 to $0.8 \mathrm{mg}$ $\mathrm{L}^{-1}$. The occurrence of cyanobacterial blooms has also been reported frequently over the last 20 years, with a predominance of Microcystis aeruginosa [30,32], including the occurrence of toxic strains [33]. Samuel reservoir $\left(08^{\circ} 45^{\prime} \mathrm{S}\right.$ and $\left.63^{\circ} 26^{\prime} \mathrm{W}\right)$ is located $52 \mathrm{~km}$ from Porto Velho city, capital of Rondônia State, west Amazon region, Brazil. It has a flooded area of $584.26 \mathrm{~km}^{2}$, flow rate of $265 \mathrm{~m}^{3} \mathrm{~s}^{-1}$, water residence time of 105 days and annual mean water temperature about $28^{\circ} \mathrm{C}$. The average of DIN and SRP observed during 2007/2008 were $0.5 \mathrm{mg} \mathrm{L}^{-1}$ and $0.08 \mathrm{mg} \mathrm{L}^{-1}$, respectively [34]. Cyanobacteria dominance was already registered in this system, represented by the species Aphanocapsa holsatica, Microcystis panniformes and Merismopedia tenuissima [34].

We sampled 5L of water from these two systems and the experiments were conducted with aliquots of $100 \mathrm{~mL}$ of non-filtered water that were transferred to $200 \mathrm{~mL}$ Erlenmeyer flasks and incubated at 25 and $30^{\circ} \mathrm{C}$, with and without addition of nutrients. The lowest temperature $\left(25^{\circ} \mathrm{C}\right)$ tested was chosen based on the annual average temperature in the water body from southeast of Brazil, and the highest temperature $\left(30^{\circ} \mathrm{C}\right)$ considered an increase of $5^{\circ} \mathrm{C}$ to the annual mean (predicted by IPCC 2013 as result of global warming) for Jacarepaguá lagoon (eutrophic system). We tested the same temperatures for Samuel reservoir (oligo-mesotrophic system), however, the $30^{\circ} \mathrm{C}$ was considered the annual mean temperature for this system and $25^{\circ} \mathrm{C}$ was $5^{\circ} \mathrm{C}$ below of the annual mean temperature. Therefore, the water from eutrophic system was increased in $5^{\circ} \mathrm{C}$ and the water from oligo-mesotrophic system was decreased the same $5^{\circ} \mathrm{C}$.

Eutrophication was simulated by the addition of nitrogen $\left(7.0 \mathrm{mg} \mathrm{N} \mathrm{L}^{-1}\right.$ as $\left.\mathrm{NaNO}_{3}\right)$ and phosphorus ( $0.8 \mathrm{mg} \mathrm{P} \mathrm{L}^{-1}$ as $\left.\mathrm{K}_{2} \mathrm{HPO}_{4}\right)$, to $\mathrm{N}+\mathrm{P}$ treatment. Flasks were closed with cellulose stopper and placed in incubators (SOLAB SL-224) under a light intensity of $60 \mu \mathrm{mol}$ photons $\mathrm{m}^{-2} \mathrm{~s}^{-1}$ provided in a photoperiod of $12 \mathrm{~h}$ and shaken manually twice every day. Both treatments were run in triplicate, and growth was monitored for seven days. Total-cyanobacteria and eukaryote chlorophyll- $a$ concentrations were measured in each flask using a PHYTO-PAM phytoplankton analyzer (Heinz Walz GmbH, Effeltrich, Germany) on days 0, 1, 4, 5, 6 and 7 for eutrophic water, and on days $0,3,5$ and 7 for oligo-mesotrophic water.

\subsection{Data Analysis}

We used the natural log transformed response ratio $\left(R R_{x}\right)$ as metric of the size effect of temperature and nutrients addition on cyanobacteria and eukaryotic algae growth rate. The response ratio of cyanobacteria ( $R R_{\text {cyano }}$ ) and eukaryote algae (RRalgae) was calculated as a ratio between the growth rate of each treatment $T\left(30^{\circ} \mathrm{C}, 25^{\circ} \mathrm{C}+\mathrm{N}+\mathrm{P}\right.$ and $\left.30^{\circ} \mathrm{C}+\mathrm{N}+\mathrm{P}\right)$ and the growth rate in the sole $25^{\circ} \mathrm{C}$ incubations (used as control, $C$ ) following $R R_{x}=\ln (T / C)$ [35], for eutrophic water system. However, to oligo-mesotrophic system, we used the growth rate in the sole $30^{\circ} \mathrm{C}$ incubations as control (C), since $30^{\circ} \mathrm{C}$ was closest the annual average water temperature of this system. A two-way ANOVA with different trophic state systems (eutrophic and oligo-mesotrophic) and phytoplankton groups (cyanobacteria and eukaryote algae) as fixed factors were performed in order to test whether temperature and nutrients addition affect the response ratio of cyanobacteria and eukaryotic algae. All the statistical analysis was performed using tool-pack SigmaPlot, Version 12 (Systat Software, Inc).

\section{Conclusion}

It is widely believed within the scientific community that global warming; and the corresponding increases in water temperatures will promote cyanobacteria blooms. Our research shows that an increase of temperature itself is not necessarily the case because; according to our results; warming alone does not significantly change the phytoplankton community; but rather the process of eutrophication contributes more to such changes than warming alone. Therefore; it is 
important to emphasize that the complete scenario described during discussions about global warming and/or climate change events consider the holistic effects of those events to water bodies; including do not only temperature or nutrient increasing but the complex interaction among physical; chemical and biological parameters as well as the frequency and intensity of those "pulses". Besides; systems with different trophic states can respond in different ways to nutrient enrichment. Eutrophic water systems were shown to have intensified cyanobacteria dominance when more nutrients were added. In contrast; oligo-mesotrophic systems showed resistance by not changing the relative contribution of phytoplankton groups. All groups of algae could be favored by eutrophication, independently of a direct temperature effect. This suggests that in eutrophic systems cyanobacteria dominance can be favoured by further addition of nutrients. Since global warming associated with extreme climatic events are assumed to intensify eutrophication symptoms indirectly; our study underscores the importance of proper water management by regulatory agencies regarding the control of nutrient content/input into water systems. In addition to this; governing bodies and regulatory agencies must work to preserve already pristine ecosystems. Furthermore; the authors suggest that the potential resilience observed in oligo-mesotrophic system from a tropical region needs to be better understand.

Acknowledgements: The work was supported by grants from Fundação de Amparo a Pesquisa do Estado do Rio de Janeiro (FAPERJ), and was conducted under auspices of the CAPES (Brazil)/NUFFIC (The Netherlands) project 045/2012. A.M.A.G. was supported by Pos-doc fellowship from PAPDJ-CAPES/FAPERJ (proc. E-26/102.863/2011), Brazil.

Author Contributions: Each author individual contribution is specified below:

AMAG - contributed to the conception of the study, collected samples, performed experiments. She participated in the analysis and interpretation of data. She worked in writing the manuscript and reviewing drafts, incorporating co-authors suggestions and approved the final version.

MMM - contributed to the conception of the study, performed experiments. He participated in the analysis and interpretation of data. He worked in writing the manuscript and reviewing drafts, and approved the final version.

MCBM - performed experiments, participated in the analysis and interpretation of data, reviewed drafts, and approved the final version.

ACCP - performed experiments, participated in the analysis and interpretation of data, reviewed drafts, and approved the final version.

ML - contributed to the conception of the study, participated in the interpretation of data, made substantial intellectual contribution. He reviewed manuscript drafts, contributed incorporating co-authors suggestions and approved the final version.

SMFOA - contributed to the conception of the study, participated in the analysis and interpretation of data. She reviewed manuscript drafts, contributed incorporating co-authors suggestions and approved the final version.

Conflicts of Interest: The authors declare no conflict of interest.

\section{References}

1. Carpenter, S.; Fisher, S.; Grimm, N.; Kitchell, J. Global change and freshwater ecosystems. Annu. Rev. Ecol. 1992, 23, 119-139. 
2. Paerl, H.; Huisman, J. Blooms like it hot. Science 2008, 320, 57-58.

3. Carey, C. C.; Ibelings, B. W.; Hoffmann, E. P.; Hamilton, D. P.; Brookes, J. D. Eco-physiological adaptations that favour freshwater cyanobacteria in a changing climate. Water Res. 2012, 46, 1394-407.

4. O'Neil, J. M.; Davis, T. W.; Burford, M. a.; Gobler, C. J. The rise of harmful cyanobacteria blooms: The potential roles of eutrophication and climate change. Harmful Algae 2012, 14, 313-334.

5. De Senerpont Domis, L. N.; Mooij, W. M.; Huisman, J. Climate-induced shifts in an experimental phytoplankton community: a mechanistic approach. Hydrobiologia 2007, 584, 403-413.

6. Jöhnk, K.; Huisman, J.; Sharples, J.; Sommeijer, B.; Visser, P.; Strooms, J. Summer heatwaves promote blooms of harmful cyanobacteria. Glob. Chang. Biol. 2008, 14, 495-512.

7. Paerl, H. W.; Paul, V. J. Climate change: links to global expansion of harmful cyanobacteria. Water Res. 2012, 46, 1349-63.

8. Conley, D. J.; Paerl, H. W.; Howarth, R. W.; Boesch, D. F.; Seitzinger, S. P.; Havens, K. E.; Lancelot, C.; Likens, G. E. Ecology. Controlling eutrophication: nitrogen and phosphorus. Science 2009, 323, 1014-5.

9. Paerl, H. W.; Huisman, J. Climate change: a catalyst for global expansion of harmful cyanobacterial blooms. Environ. Microbiol. Rep. 2009, 1, 27-37.

10. Hansen, J.; Sato, M.; Ruedy, R.; Lacis, a; Oinas, V. Global warming in the twenty-first century: an alternative scenario. Proc. Natl. Acad. Sci. U. S. A. 2000, 97, 9875-80.

11. Tilman, D.; Lehman, C. Human-caused environmental change: impacts on plant diversity and evolution. Proc. Natl. Acad. Sci. U. S. A. 2001, 98, 5433-40.

12. Rigosi, A.; Carey, C. C.; Ibelings, B. W.; Brookes, J. D. The interaction between climate warming and eutrophication to promote cyanobacteria is dependent on trophic state and varies among taxa. Limnol. Oceanogr. 2014, 59, 99-114.

13. De Senerpont Domis, L. N.; Elser, J. J.; Gsell, A. S.; Huszar, V. L. M.; Ibelings, B. W.; Jeppesen, E.; Kosten, S.; Mooij, W. M.; Roland, F.; Sommer, U.; Van Donk, E.; Winder, M.; Lürling, M. Plankton dynamics under different climatic conditions in space and time. Freshw. Biol. 2013, 58, 463-482.

14. Brookes, J. D.; Carey, C. C. Resilience to Blooms. Ecology 2011, 334, 46-47.

15. Reynolds, C.; Huszar, V. Towards a functional classification of the freshwater phytoplankton. J. Plankton Res. 2002, 24, 417-428.

16. Lürling, M.; Eshetu, F.; Faassen, E. J.; Kosten, S.; Huszar, V. L. M. Comparison of cyanobacterial and green algal growth rates at different temperatures. Freshw. Biol. 2013, 58, 552-559.

17. Watson, S. B.; McCauley, E.; Downing, J. A. Patterns in phytoplankton taxo- nomic composition across temperate lakes of differing nutrient status. Limnol. Oceanogr. 1997, 42, 487-495.

18. Kosten, S.; Huszar, V. L. M.; Bécares, E.; Costa, L. S.; Donk, E.; Hansson, L.-A.; Jeppesen, E.; Kruk, C.; Lacerot, G.; Mazzeo, N.; Meester, L.; Moss, B.; Lürling, M.; Nõges, T.; Romo, S.; Scheffer, M. Warmer climates boost cyanobacterial dominance in shallow lakes. Glob. Chang. Biol. 2012, 18, 118-126.

19. Lopes, M. R. M.; Bicudo, C. E. D. M.; Ferragut, M. C. Short term spatial and temporal variation of phytoplankton in a shallow tropical oligotrophic reservoir, southeast Brazil. Hydrobiologia 2005, 542, 235-247.

20. Soares, M. C. S.; Marinho, M. M.; Huszar, V. L. M.; Branco, C. W. C.; Azevedo, S. M. F. O. The effects of water retention time and watershed features on the limnology of two tropical reservoirs in Brazil. Lakes Reserv. Res. Manag. 2008, 13, 257-269.

21. Marinho, M.; Huszar, V. L. M. Nutrient availability and physical conditions as controlling factors of phytoplankton composition and biomass in tropical reservoir. Arch. fuer Hydrobiol. 2002, 153, 443-468.

22. Soares, M.; de A Rocha, M.; Marinho, M.; Azevedo, S.; Branco, C.; Huszar, V. Changes in species composition during annual cyanobacterial dominance in a tropical reservoir: physical factors, nutrients and grazing effects. Aquat. Microb. Ecol. 2009, 57, 137-149.

23. Rangel, L.; Silva, L.; Rosa, P.; Roland, F.; Huszar, V. Phytoplankton biomass is mainly controlled by hydrology and phosphorus concentrations in tropical hydroelectric reservoirs. Hydrobiologia 2012, 693, 13-28.

24. Molisani, M. M.; Barroso, H. D. S.; Becker, H.; Moreira, M. O. P.; Hijo, C. A. G.; Monte, T. M. Do; Vasconcellos, G. H. Trophic state, phytoplankton assemblages and limnological diagnosis of the Castanhão Reservoir, CE, Brazil. Acta Limnol. Bras. 2010, 22, 1-12. 
25. Moss, B.; Kosten, S.; Meerhof, M.; Battarbee, R. W.; Jeppesen, E.; Mazzeo, N.; Havens, K.; Lacerot, G.; Liu, Z.; Meester, L. De; Paerl, H. W.; Scheffer, M. Allied attack: climate change and eutrophication. Inl. Waters 2011, 101-105.

26. Huber, V.; Wagner, C.; Gerten, D.; Adrian, R. To bloom or not to bloom: contrasting responses of cyanobacteria to recent heat waves explained by critical thresholds of abiotic drivers. Oecologia 2012, 169, 245-56.

27. Johnston, B. R.; Jacoby, J. M. Cyanobacterial toxicity and migration in a mesotrophic lake in western Washington, USA. Hydrobiologia 2003, 495, 79-91.

28. Kosten, S.; Kamarainen, A.; Jeppesen, E.; Van Nes, E. H.; Peeters, E. T. H. M.; Mazzeo, N.; Sass, L.; Hauxwell, J.; Hansel-Welch, N.; Lauridsen, T. L.; Søndergaard, M.; Bachmann, R. W.; Lacerot, G.; Scheffer, M. Climate-related differences in the dominance of submerged macrophytes in shallow lakes. Glob. Chang. Biol. 2009, 15, 2503-2517.

29. Jeppesen, E.; Sondergaard, M.; Jensen, J. P. Climatic warming and regime shifts in lake food webs-some comments. Limnol. Oceanogr. 2003, 48, 1346-1349.

30. Gomes, A.; Sampaio, P.; Ferrão-Filho, A. S.; Magalhaes, V. F.; Manzi, M.; Oliveira, A.; Santos, V.; Domingos, P.; Azevedo, S. M. F. D. O. Florações de cianobactérias tóxicas em uma lagoa costeira hipereutrófica do Rio de Janeiro/RJ (Brasil) e suas consequências para saúde humana. Oecologia Bras. 2009, 13, 329-345.

31. Saieg-Filho, E. Ecologia do Fitoplâncton Marginal das Lagunas da Baixada de Jacarepaguá, Universidade do Estado do Rio de Janeiro, 1986, p. 150.

32. Ferrão-Filho, A. S.; Domingos, P.; Azevedo, S. M. F. D. O. E. Influences of a Microcystis aeruginosa Kutzing bloom on zooplankton populations in Jacarepagua Lagoon (Rio de Janeiro, Brazil). Limnol. - Ecol. Manag. Inl. Waters 2002, 32, 295-308.

33. Magalhães, V. F. de; Soares, R. M.; Azevedo, S. M. F. D. O. Microcystin contamination in fish from the Jacarepaguá Lagoon (Rio de Janeiro, Brazil): ecological implication and human health risk. Toxicon 2001, 39, 1077-1085.

34. Nascimento, E. L. Fatores ambientais reguladores da dinâmica de cianobactérias no reservatório da Usina Hidrelétrica de Samuel, Rondônia (Amazônia Ocidental, Brasil), Federal University of Rio de Janeiro, 2012, p. 187.

35. Elser, J. J.; Bracken, M. E. S.; Cleland, E. E.; Gruner, D. S.; Harpole, W. S.; Hillebrand, H.; Ngai, J. T.; Seabloom, E. W.; Shurin, J. B.; Smith, J. E. Global analysis of nitrogen and phosphorus limitation of primary producers in freshwater, marine and terrestrial ecosystems. Ecol. Lett. 2007, 10, 1135-42. 